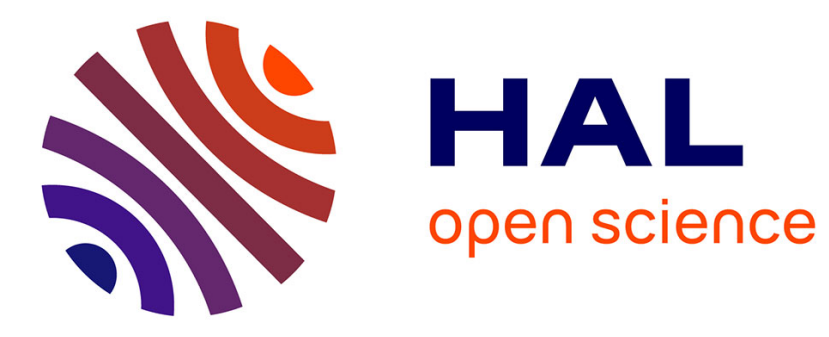

\title{
Translation and Communism in Eastern Europe Ioana Popa
}

\section{To cite this version:}

Ioana Popa. Translation and Communism in Eastern Europe. Fruela Fernandez; Jonathan Evans,London. The Routledge Handbook of Translation and Politics, Routledge, pp.424-441, 2018, 9781138657564. 10.4324/9781315621289-28 . hal-02377774

\section{HAL Id: hal-02377774 https://hal.science/hal-02377774}

Submitted on 1 Sep 2021

HAL is a multi-disciplinary open access archive for the deposit and dissemination of scientific research documents, whether they are published or not. The documents may come from teaching and research institutions in France or abroad, or from public or private research centers.
L'archive ouverte pluridisciplinaire HAL, est destinée au dépôt et à la diffusion de documents scientifiques de niveau recherche, publiés ou non, émanant des établissements d'enseignement et de recherche français ou étrangers, des laboratoires publics ou privés. 
Popa I., "Translation and Communism in Eastern Europe", in Fruela Fernandez and Jonathan Evans (eds.), Routledge Handbook of Translation and Politics, London, Routledge, 2018, pp. 424-441

\section{Translation and Communism in Eastern Europe}

Ioana Popa (CNRS)

The Eastern European area constitutes a valuable vantage point for looking at the relationship and interactions between literary translation and politics. This observation has nothing to do with culturalist explanations attributing some sort of 'ontological essence' to this area, or a set of intrinsic and 'typical' cultural patterns that are supposed to determine all of its characteristics. Instead, the prominence of this relationship can be traced to social and historical backgrounds and long-term intellectual and political trends. It also stems from more general links between literature per se, language and politics, as these fields have taken shape in Eastern Europe. Moreover, these links can be usefully explored by considering the transfer of literature not simply across national borders, but also across a 'transsystemic' border (Péteri 2004), e.g. one that separated two contrasted geopolitical systems, as did the Iron Curtain (Popa 2002, 2006). In that sense, Eastern Europe represents an interesting study site indeed. Translation reveals the interplay between literary transfers and politics especially during an historical context marked by the rise of undemocratic regimes, such as those claiming to be communist in this part of the European continent, as well as by the Cold War, which traditional scholarship regards as an historical stage of the international system moulded by confrontation, rivalry, and a hermetic divide between the capitalist and socialist worlds.

Rooted in an internationalist ideology intended to expand worldwide, communist regimes were implemented in Eastern Europe mainly after the Second World War, being predated by the Bolshevik Revolution in 1917. They deeply transformed cultural production and diffusion in the countries where they came to power and also shaped the politics of translation, fostering it according to ideological criteria or, on the contrary, curbing or preventing it through various forms of control and even repression. Moreover, both rival geopolitical camps envisaged the international circulation of literary works as a means of the intellectual Cold War. 'Eastern Europe' is in itself a category that was partly moulded during this period. It acquired significance by naming the part of the European continent where these regimes seized power. Like other regions and geographical opposite pairs (such as 'East' vs. 'West'), 'Eastern Europe' is an intellectual construct (Lewis and Wien 1997; Todorova 1997; Wolff 1994, among others) and part of a recurring conceptual remapping of the region (the inflections of which could be 'Central', 'Oriental', 'Southeastern' Europe, etc.) that corresponded to fluctuating criteria and geographic boundaries. Although it goes with a geopolitical definition of the area, 'Eastern Europe' is far from an unproblematic category that would designate a unified reality sharing identical cultural, linguistic, economic, and political characteristics. Furthermore, from the specific angle of the international circulation of literary texts by means of translation, Eastern Europe cannot be considered a homogenous unit during the communist period.

Surprisingly, scholarly literature on Communism and Eastern Europe has been largely overlooked translation issues, as did for instance studies dealing with the language policies 
Popa I., "Translation and Communism in Eastern Europe", in Fruela Fernandez and Jonathan Evans (eds.), Routledge Handbook of Translation and Politics, London, Routledge, 2018, pp. 424-441

in that region (Gorhal 2003; Grenoble 2003, for example). Cultural history (Friedberg 1997; Leighton 1991; Thomson-Wohlgemuth 2009) and historical sociology of Cold War Communism (Popa 2010) have only quite recently been enriched with monographic and book-length works on translation, in spite of the increasing attention that the social and political sciences have paid to various forms of circulation of ideas beyond the Iron Curtain and within the socialist camp. Likewise, in the domain of translation studies, research on this particular historical context (Popa 2013) has been mostly limited to case studies included in edited volumes (Baer 2011). Often, these collective works covered much more varied empirical and geographical situations than Eastern Europe, while focusing in particular on the relationship between translation and censorship, ideology, power, as well as resistance and activism.

Since the establishment of communist regimes in Eastern Europe gave even more prominence to extra-textual (in particular, political) factors that shaped translation practices, the study of such a geopolitical area fosters the inscription of translation into general social processes, enabling research to go beyond mere textual approaches. As a subject of study in its own right in this historical context, translation can foster a sound knowledge of pertinent approaches and conceptual and methodological achievements in history, sociology, political science, and translation studies, thus increasing multidisciplinary work. Moreover, scholars can benefit from historical distance from the object of study, which makes available sources that were previously censored or inaccessible. It spurs scholars to anchor their analyses in solid data and thus to nourish well-framed historical and sociological inquiries, going beyond drafting essays in a loose way. At the same time, the acquisition of multidisciplinary and indepth knowledge of this issue allows scholars to avoid thinking that the study of such a geographic region under communism, and more generally, of translation practices under undemocratic regimes, requires methods of investigation that are completely different from those used by the social and political sciences for 'ordinary' situations. In other words, breaking down boundaries between disciplinary approaches about translation prevents scholars from believing that a 'methodological exceptionalism' (Dobry 2003) should characterise the study of these political regimes and the social practices related to this particular issue.

\section{INTERPLAY BETWEEN TRANSLATION AND POLITICS: HISTORICAL BACKGROUNDS}

The ways in which translation and politics interacted in Eastern Europe have a history that stretches beyond the communist period; long-term intellectual, social and political trends shaped part of the developments that occurred during this recent era.

Even before communist regimes took power, the differentiation of the social space and the degree of autonomy of specific social fields, including the literary sphere (Bourdieu 1992), were rather limited in this part of the European continent. This fact is partly attributable to characteristics of the social structure that had been established there since the advent of the Middle Ages and the modern era (Konràd and Szelényi 1979). Moreover, before the Second World War, democratic traditions were still fragile, if not completely absent. On the contrary, long-standing traditions of political censorship limited freedom of expression and creation, such as the severe restrictions on publishing promulgated under the Russian Empire (Rudd 2009). Since the second half of the $17^{\text {th }}$ century, Russian political interference had also been apparent in overseeing literature published in the Kingdom of Poland, whose first partition led also to increased control on publishing (Tomaszkiewicz 
Popa I., "Translation and Communism in Eastern Europe", in Fruela Fernandez and Jonathan Evans (eds.), Routledge Handbook of Translation and Politics, London, Routledge, 2018, pp. 424-441

2002: 171-172). Censorship restricted translation practices as well (Friedberg 1997: 140-141; Tax Choldin 1985), while also contributing to the construction of translation as a locus of resistance as well as of political subversion.

Other factors that favoured interaction between politics and translation issues derived from the long-lasting existence of multi-ethnic empires in this region. This situation came hand in hand with the non-congruence and instability of political, national, ethnic, linguistic and cultural boundaries, as well as with multilingual contexts. Conversely, it fostered theories, agendas and movements in favour of nation-building, political unity and independence of the nation state. These orientations stipulated that language was a key element in defining national identity, thereby giving a significant role to language policies and placing emphasis on translating as well.

Multilingualism was indeed a frequent situation in Central, Eastern, and Southeastern Europe. Moreover, proficiency not only in the vernacular and official language, but also in Western language(s) was usual. Social elites viewed the latter as prestigious and commonly used them. These multiple skills could make translation superfluous because they enabled direct access to original texts; however, they also facilitated translation. Thus, multilingualism shaped, blurred and complexified the geography drawn by the translation flows. A relevant example could be the plurality of linguistic configurations that coexisted traditionally within the territorial boundaries of the present-day Slovakia. Several languages were used: Old Slavonic; 'slovakised' Czech; various versions of Old Slovak; the codified and standardized Slovak in the late $18^{\text {th }}$ century; Latin, which was used by educated readers until the $19^{\text {th }}$ century; and finally German and Hungarian, which became official languages during the $19^{\text {th }}$ century. This situation also led to the parcelling of the literary space in the process of taking shape, while the vernacular literary tradition varied from one land to another. It triggered the translation into modern Slovak of literary works that had been written in Old Slavonic, on the one hand, in Latin and German, on the other, even as recently as the 1920s and the second half of $20^{\text {th }}$ century, respectively (Bednárová 2013: 250). Moreover, the Czech language was used for making indirect translations into Slovak. Translation from Czech to Slovak and vice versa reached back to the mid-19 ${ }^{\text {th }}$ century and became even more frequent during the second half of the $20^{\text {th }}$ century. This process had cultural benefits but also political significance, since it reassured the distinctiveness between these languages and could even herald distinct national identities. The growing emancipation of Slovak literary translation from the Czech language became evident, especially from the 1970s onwards, through increased direct translations into Slovak, including those of Czech literature.

Translation was indeed a useful means for the building up of national literatures. It helped assert national aspirations by contributing to elevating vernacular languages to the status of a national literary languages, to enrich them with a diversity of styles and speech registers, as well as with new aesthetic and thematic tendencies, and finally, to establish standardised language and literary norms. At the same time, the domination of foreign states over heterogeneous populations led to the marginalisation, if not the banning of vernacular languages in the official spheres. This situation had ambivalent effects, since it hindered numerous cultural and publishing activities, but also fostered their relocation abroad and the circumvention of the restrictions. Therefore, the codification of modern languages and their use through translating were a step in the conquest of national independence. Various studies have examined these processes, such as in the case of the Ukrainian language and literature. An edict signed in 1876 by the Emperor Alexander II of 
Popa I., "Translation and Communism in Eastern Europe", in Fruela Fernandez and Jonathan Evans (eds.), Routledge Handbook of Translation and Politics, London, Routledge, 2018, pp. 424-441

Russia expressly banned translations into, and the importation from abroad of publications written in, this language (Chernetsky 2011: 40; Shevelov 1989, among others).

Nation-building as well as the construction of political unity or state independence also gave an important status to writers themselves (Wachtel 2006; Pynsent 1996; Konràd and Szelényi 1979). They were heralded as national symbols, such as the Ukrainian Taras Shevchenko, the Pole Adam Mickiewicz, the Hungarian Sándor Petöfi, or the Bulgarian Christo Botev; some of them even played an actual political role. Conversely, this role would become a long-term source of prestige, status and symbolic power for the literary profession, while it enhanced the collusions between the literary and political spheres. Some of these writers would still be recognised as part of the literary canon after the establishment of the communist regimes, which presented them as supposed forerunners of the socialist literature. Consequently, their works would be promoted abroad through translation as well. Under specific circumstances, such as in the young German Democratic Republic (GDR), translation could regain a national mission, since it would be intended to support the construction of an East German identity (Thomson-Wohlgemuth 2009: 108).

Various scholars have underscored the role played by translated literature also during the 'modernisation' process (sometimes called 'Westernisation') initiated at various times in different Eastern European countries, such as in Russia during the reigns of Pierre the Great and Catherine the Great. For example, an Association for the Advancement of the Translation of Foreign Books into Russian was created in 1768 (Baer 2011: 4; Friedberg 1997: 34). Other modernisation programmes viewed translation as a means to overcome countries' self-perception as being isolated and peripheral, as well as culturally and economically backwards (in light of Western countries' standards), while others, on the contrary, criticised translation as a form of servile imitation of foreign cultures. This antagonism can be seen, for instance, in the debates that occurred in the Romanian Countries during the $19^{\text {th }}$ century, and then following their political unification and in the interwar period. The debate between 'imported' vs. 'indigenous', 'foreign' vs. 'native' creations and values resurfaced under the communist regime (Deletant 1996; Verdery 1991). This controversy was revived in the 1970s, mainly by writers who were proponents of the 'Romanian protochronism', that is, advocated the value of the 'indigenous' and argued that Romanian literature and culture had often pre-empted Western literatures. In this vein, it seemed unnecessary to encourage translation of foreign works. Therefore, an isolationist cultural policy was a warranted option. From the mid-1970s onwards, translations from Western countries and even those from other socialist countries into the Romanian language were even more drastically selected (Ionescu 2010: 238; Antochi 2012). This 'nationalist' line was a further reason behind the communist regime's reluctance to expose its readership to the potential danger of ideas that came from the other side of the Iron Curtain.

\section{REASSESSING APPROACHES ON COLD WAR COMMUNISM: TRANSLATION AS A VANTAGE POINT}

Traditional scholarship, as well as common perceptions of Cold War communism, place emphasis on the impervious aspect of the East-West divide and on the considerable limitations on travel and circulation of ideas and (cultural) goods to and from Eastern Europe, at the expense of any East-West connection. It also underlines dual competition (e.g. the US vs. the USSR) to the detriment of 'small' players of the international system, as well as the role of state actors and inter-governmental relationships, whereas non-state 
Popa I., "Translation and Communism in Eastern Europe", in Fruela Fernandez and Jonathan Evans (eds.), Routledge Handbook of Translation and Politics, London, Routledge, 2018, pp. 424-441

players and transnational networks were deemed irrelevant, in accordance with the realist paradigm which dominated the study of international relations for a long time. Moreover, in these conventional perspectives, political, diplomatic, military and economic categories were dominant in the comprehension of Cold War systemic rivalries, at the expense of their cultural components. However, some recent studies have reconsidered these perspectives (among them, Westad 2000; Péteri 2004; Autio-Sarasmo and Miklossy, 2011; Villaume and Westad 2010; David-Fox 2011a). These studies have called more or less overtly for a new Cold War history highlighting trends opposite to those mentioned above. Therefore, these new approaches aspire to be multipolar and even global, to give increased attention to a transnational approach to Cold war relations and to non-governmental actors, to herald a 'cultural turn' in Cold War studies (Johnston 2010) and to consider circulatory processes across the Iron Curtain and within the socialist camp - as a useful prism through which the East-West relationship can be viewed.

Moreover, based on new documentary sources, research on Eastern European communist regimes themselves has expanded and gradually evolved since their ending. However, one of the main debates that has previously underlaid such research still persisted. It contrasts a totalitarian view of communism with social history approaches that were promoted by the so-called revisionist school. The totalitarian approach (Friedrich and Brezinski 1956, among others) stresses the overall pre-eminence of the single (Communist) party, its total control of the state apparatus and of all the spheres of society, as well as its monolithic nature, the extreme centralisation of political power, and the primacy of ideology, infusing all the aspects of the social life. While supporters of this approach assert that the social, economic and cultural organisation derives from politics (Malia 1994, among others), proponents of social history underline the role of social groups 'from below' and the vestiges of competing interests, considering them to be partly able to circumvent the control of the one-party state and even to oppose it (among others, Fitzpatrick 1986). They also pay attention to the internal contradictions, structural deficiencies and to the inefficiency of communist regimes.

Questionings on such aspects also permeate existing studies about translation even if they are generally not connected with these historiographical and theoretical debates because of disciplinary compartmentalisations. Conversely, such studies can enrich our understanding of the functioning of the cultural sphere under communist regimes, as well as of their international/transnational dimensions. Indeed, in such a geopolitical context, translation is a good vantage point for shedding light, first of all, on the social, political, economic, intellectual and linguistic (im)possibility of opening up official and informal connections across the East-West divide (Popa 2006, 2010). As it offers a guided thread for grasping such links through flows of ideas which are materialised in printed books and manuscripts, it allows us to question the forms and levels of the cultural isolation of communist regimes. While the concept of 'totalitarianism' provides an unchanging backdrop, homogenises the ways of exercising power and control, and gives credence to the idea of a hermetic and permanent isolation of these regimes, empirical studies focusing on translation can reconstitute situations that are more complex than this picture.

These studies also help distinguish phases of literary transfer according to particular historical contexts. For instance, a study of Internacional'naja Literatura (Safiullina and Platonov 2012), a Soviet journal entirely devoted to the translated literature, shows that the dissemination of foreign literature in the USSR was surprisingly free until the mid-1930s, as Internacional'naja Literatura operated with less restraint than other periodicals. Censorship 
Popa I., "Translation and Communism in Eastern Europe", in Fruela Fernandez and Jonathan Evans (eds.), Routledge Handbook of Translation and Politics, London, Routledge, 2018, pp. 424-441

and restrictions placed on foreign (including Western) literature were less rigorous and rather unsystematic than those applied to domestic literature during the 1920s and 1930s (see also Witt 2011: 155; Friedberg 1997: 112). This situation was due to the 'relative weakness and inefficiency of direct Party control' (Safiullina and Platonov 2012: 254) and, until the Great Purges (1936-1938), went hand in hand with the significant role of individuals and of personal initiatives in obtaining, translating and publishing foreign literature. Other recent studies (Clark 2010; David-Fox 2011b) provide an insight on the international dimension and international connections, still underestimated or insufficiently studied. As such, they contribute to the understanding of the interwar Stalinist culture and more generally, of the formation of the Soviet system, usually considered only through 'internalist' approaches and seen as one of the most isolationist and autarkic regimes of the $20^{\text {th }}$ century (David-Fox 2011a).

Yet, what is at stake here is not the denial of constraining geopolitical borders and limits, of the selectiveness of crossing them, and of the authoritarian exercise of power, but rather the understanding of their variability, modulations and inflections that nurtured successive openings and closings of the communist regimes. Communist experiences therefore cannot be conceived as a constant, homogenous or a unified phenomenon. Moreover, overcoming a view of Soviet communism in terms of totalitarianism and isolationism does not mean neglecting the pursuit of USSR's cultural hegemony and 'imperial dominance' (Clark 2010) through external cultural action, which was deployed by means of translation as well. The Soviet cultural diplomacy (David-Fox 2011a) illustrates this phenomenon. Its apparatus crystallised in the early 1920 s and diversified gradually. Internacional'naja Literatura was one of its instruments, since the journal was also published in several foreign languages, was meant to showcase the achievements of the communist regime to a foreign readership and thus, to build up political support from Western sympathisers. The innovative interwar methods of Soviet cultural diplomacy inspired and fuelled the all-out Soviet propaganda efforts during the Second World War, and then those of the cultural Cold War, the superpower ideological competition as well as the anti-Western and 'anti-cosmopolitan' campaigns of the Zhdanov period.

The tension between cultural isolationism and nationalism, on the one hand, and the harshness of the Soviet public diplomacy and external diffusion of the realist socialist model of creation, on the other, culminated during this phase of the early Cold War (Baudin and Heller 1998). An enriched institutional machinery took on the construction and dissemination abroad of the USSR'S brand image and accomplishments through cultural productions. It was also supported by the infrastructures of foreign Communist parties, including those created in Western countries. This Soviet export policy also inspired the cultural diplomacies of the people's democracies newly established in Eastern Europe and the infrastructures they created in order to promote and disseminate their literatures abroad, albeit on a smaller scale and with more limited resources.

Studies focusing on translation flows to and from people's democracies frequently mention even more general and profound transformations of the cultural sphere: nationalisation of the cultural institutions, centralisation, planning, censorship and pervasiveness of ideology. Prohibitions and repression accompanied changes. For these reasons, some of these studies borrowed the concept of 'totalitarianism' (or its derived adjectives) for describing communist regimes or at least particular historical contexts they went through (Witt 2011; Monticelli 2011). However, other analyses considered translation to be an appropriate vantage point for observing plural, non-congruent, and even 
Popa I., "Translation and Communism in Eastern Europe", in Fruela Fernandez and Jonathan Evans (eds.), Routledge Handbook of Translation and Politics, London, Routledge, 2018, pp. 424-441

ambivalent and contradictory processes (Popa 2010) regarded as relevant for the nonmonolithic structuring of the cultural sphere and the differentiated functioning of literary transfers under communism. Following this perspective, the forms of state's hold over international cultural transfers framed, controlled, and restricted the politics of translation, transforming it into a means of promotion and in a symbolic reward for official writers' loyalty towards the political power and, as we have already seen, put it at the service of external propaganda. But at the same time, translation also reveals dysfunctions in these forms of political control. It allows examining the ways in which rules could be circumvented, the room for manoeuvre of publishers, translators, authors and other cultural players in face of these constraints, and the ways in which translation contributed to the importation into the socialist countries, as well as the exportation, of literary stances that were forbidden by their authorities.

Studies of translation issues have generally focused on one or the other of these facets - control and censorship on the one hand; the means of subversion and resistance through translation, on the other hand - at times also going back and forth between them. A significant portion of these studies is thus dedicated to the forms of censorship before and during the translation process and to their effects on the editorial selection. The attention paid mainly to this preventive censorship did not exclude mentioning the repressive censorship as well. The latter took the form of prohibitions of a translated text after its publication, because of its content or its author's and/or translator's identity, and could even lead to the suspension or the persecution of journals or publishing houses that were held accountable for a controversial publication. Textual aspects are the issues that have been especially taken into consideration by existing studies; but institutional aspects of censorship, as well as the entanglement of multiple institutional and individual players involved in the process, have also been examined or at least mentioned. Highlighting the multiple localities of censorship rather than its centralisation gives thus a nuanced view of the control practices shaping translation, yielding a picture that is different from that of topdown interpretations often associated with the totalitarian paradigm. Several actors and institutions - not only those officially labelled as censors, but also publishers, translators, reviewers, and even writers themselves - illustrate this variety of stakeholders, whose social and professional characteristics and interests could be specific to each other. Unequal power relationships, along with negotiations and arrangements, characterised their interactions, as one can observe for example through the arguments put forward in order to obtain the print permit, which have been analysed in the case of the translation of children' literature in the GDR (Thomson-Wohlgemuth 2007: 108-114, 2009: 116 sq.). Moreover, these players did not always carry out clear or unequivocal instructions, excepted some topics that were explicitly banned (antisocialist or anti-Soviet standpoints, religious and sexual themes, etc.). These dynamics resulted in multifaceted practices of censorship, in spite of a system that seemed monolithic at first sight (Sherry 2010: 2-5; Leighton 1991: 45; Looby 2008). Correlatively, these practices did not limit to textual changes. They could include self-censorship, selection of the books deemed suitable for a socialist readership (Skibińska 2006, Špirk 2008, among others) or for being translated abroad (Popa 2002, 2010), as well as economic pressures, such as access to paper and to foreign currency, printing facilities, and the size of a book's print run (Thomson-Wohlgemuth 2007; Antochi 2012: 260).

Examination of textual strategies, along with contrastive analyses of the original and translated texts, constitutes a considerable part of the research conducted. Additions, suppressions, lexical alterations, and changes of connotational meanings brought translated 
Popa I., "Translation and Communism in Eastern Europe", in Fruela Fernandez and Jonathan Evans (eds.), Routledge Handbook of Translation and Politics, London, Routledge, 2018, pp. 424-441

texts closer to the Marxist-Leninist terminology, thus favouring their incorporation into the official literary canon. The instruments enabling publishers to 'regulate the reception' (Sherry 2010: 12) also included the paratext(s), such as introductions, prefaces, footnotes and commentaries. They served to indicate how translated works 'should' be read and could also be used as subterfuges for circumventing censorship, keeping tactical distance from the stances defended in these works, and thus safeguarding all those who were responsible for their selection, translation and publication (Ionescu 2010: 239; Rădulescu 2010; ThomsonWohlgemuth 2007: 227; Looby 2008: 58). Moreover, publishing strategies could help make translated works acceptable and even mitigate their impact intentionally by choosing publishing houses or collections that were not specialised in literature. Small print runs could also be considered as a protective strategy for controversial books.

These combinations of translating, rewriting, and editing practices contributed to produce 'custom-made versions of foreign works for domestic readers' (Tax-Choldin 1986: 336), in accordance with the communist ideology. In that sense, censorship was a 'productive action' (Sherry: 12; Inggs 2012: 79, 82). Yet, it also counted on readers' capacity to decode, if necessary, subversive or forbidden messages and oppositional stances (Baer 2006: 538-539). Thanks to the translator's ability to get around what was politically impossible to say, translation had a place within the system of the so-called 'Aesopian' language and writing practices, which designed euphemised or indirect political criticism embedded in literary texts (Loseff 1984). Studies concerning the USSR linked these aspects to older traditions of politicising translation and of state control (Baer 2006; Tax-Choldin 1986). Translation could favour resistance practices also by externalising and making known beyond the Iron Curtain forbidden texts and critical stances (Popa 2010: 245-310; 387-533). As it provided access to western intellectual spaces, translation helped prohibited authors acquire visibility and gain prominence that compensated for the reputation that had been denied to them in their own countries, and even protected them from repression.

\section{DIFFERENTIATED TRANSFERS AND TRANSLATION CHANNELS}

Recent attention paid to cultural transfers across the Iron Curtain that broke with previous Cold War Communism approaches focused on a strict East-West divide also acknowledged that these transfers were not one-sided, but operated in both these directions. However, it should not overshadow the internal transfers within the Soviet Union and the Socialist world itself. Moreover, 'East' and 'West' were not homogenous locations of these transfers and did not rule out multipolar relations. Yet, the limitations of current research do not allow mapping, quantifying or comparing systematically all the translation flows whose 'hub' was Eastern Europe. Such cumulative data would make it possible to sketch out a sort of 'geopolitics' of translation, as favoured by political affinities (backed up by Socialist countries' internationalist aims and 'friendship') or, on the contrary, curbed because of ideological cleavages (particularly East-West, but sometimes also internal to the socialist world). Aside from these geopolitical considerations, linguistic rationales also contributed to differentiate these international circulations, since focusing on translations into central and semi-peripheral or, on the contrary, peripheral and non-hegemonic languages (Swaan 1993, Heilbron 1999) shapes the map of translation flows, as well as their consistency. All in all, it is likely that one may bring to light uneven and contrasted West-to-East, East-to-East and Eastto-West literary translation flows, according to the countries that are taken as the source of these transfers, and conversely, as their target. These flows singled out not only 
Popa I., "Translation and Communism in Eastern Europe", in Fruela Fernandez and Jonathan Evans (eds.), Routledge Handbook of Translation and Politics, London, Routledge, 2018, pp. 424-441

quantitatively, but also by their contents and even the social characteristics of their intermediaries. They also reveal the persistence of symbolic hierarchies between the national literary fields under consideration. More fundamentally, the maintaining of differentiated literary transfers shows that political constraints - even when they are the result of undemocratic and very restrictive regimes that shared a common ideological project - failed to erase variations attributable to domestic backgrounds of the countries in which these regimes were established.

The bulk of the existing research focuses on a specific Eastern European socialist country at the receiving end of the translation, and consists of case studies. These studies may choose a broad historical overview, as did Friedberg (1997), whose analyses devoted to the Soviet period are part of a wider cultural history of literary translation in Russia dating back to previous centuries. On the contrary, other analyses give priority to specific periods during the Cold War era (Špirk 2008; Monticelli 2011 for example). Moreover, some of them focused on the translation of a particular Western literature (Skibińska 2006; Špirk 2008; Berger 2013). They could associate this choice with the attention paid to particular literary movements, such as the Latin American Magical Realism, whose representatives' works were translated in Romania for instance (Dimitriu 2006: 60-63), and had a significant literary as well as political impact. Studies targeted literary genres as well, such as drama (Antochi 2012) and children's literature (Thomson-Wohlgemuth 2009; Inggs 2012, among others), shedding light on their aesthetic interest as well as political issues. The scope of other studies could also be narrowed down from general flows to the reception of a particular author, making it possible to gain better insight into overall trends in translation policies and practices after the rise of communism (Dimitriu 2000). Moreover, a sizeable portion of the research devoted to West-to-East flows is related to censorship issues as well, and underlined that, especially during the early Cold war, selected Western books had to fit official aesthetics of communist regimes, Socialist Realism.

These ideological proximities were obviously greater within the socialist camp and were reinforced by the institutionalised cooperation between the Writers' Unions (Dragomir 2004: 160-166). Exchange agreements provided for translations and common literary anthologies, while direct contacts favoured the knowledge of the literature, writers and translators of other Eastern European countries. Although these East-to-East translation flows did not escape control, limitation and ideological vigilance either, scholars have noted that translations in one socialist country of works originating in another one were subject to less censorship than those imported from capitalist countries. Studies underscored another trend: the substantial growth of translations from the Russian language, as a correlate of the formation of a political and cultural Soviet sphere of influence over its 'satellites'. In these countries, translations of Soviet literature thus acquired quantitative and symbolic preeminence, as well as prescriptive force, especially when imposing Socialist Realism as the single creative method. Some of these studies go so far as to speak of 'totalitarian translation' (Monticelli 2011: 190-192) in order to describe a situation where not only did translations have a strong position in book production, but also one single language and literature-source was in a hegemonic position for the translating activity, thus erasing other external influences and even domestic literature. For example, according to Monticelli (2011: 188), 86\% of the translations published in Estonia between 1940 and 1954 (apart from the period of the German occupation) were translations from Russian.

However, factors other than communist internationalism transformed into political injunction could favour East-to-East translation flows. Such was the case of pan-Slavic ideals, 
Popa I., "Translation and Communism in Eastern Europe", in Fruela Fernandez and Jonathan Evans (eds.), Routledge Handbook of Translation and Politics, London, Routledge, 2018, pp. 424-441

which partly relied on, and favoured translation. These affinities, the proximity between Slavic languages, and the international diffusion of literatures they fostered, backed the new ideological voluntarism. Thus, at least in some Eastern European countries, such as Czechoslovakia, the massive importation of Russian literature after the Second World War relied on both these rationales and accelerated a movement under way since the $19^{\text {th }}$ century. The Russian language was also already used to make indirect translations into the Slovak language from other languages of the Soviet republics (Bednárová 2015: 86-87). However, geopolitical factors could disrupt such ancient ties. For example, the deterioration in political relations between Yugoslavia and Czechoslovakia during the 1948-1956 period adversely impacted translations of Serbian literature, whose transfer had been developed since the $19^{\text {th }}$ century.

Other specific issues concerning East-to-East translations flows were formulated about translation within the context of the Federal Union of Soviet Republics. Following on Friedberg (1997: 172-177) and Leighton (1991: 13, 18), Witt (2011) emphasised the importance of studying literary translation on the scale of a multinational state in which translation became a matter of the nationalities policy, was considered as a tool for communication between them and the construction of a common identity. The originality of this translation context consists notably in the considerable number of languages concerned and the supposed ideological coherence underlying it. But even at this scale, the preeminence of Russian language and literature prompts questions about the maintaining of political, cultural and linguistic hierarchies.

Finally, the East-to-West literary transfers could cover two contrasted cases, according to the characteristics of the political regime in the countries where works were translated. The first specific case concerns reception within regimes that were also authoritarian and undemocratic. Studies of Czech and Slovak translations published in Salazar's Portugal (Špirk 2014) and in Franco's Spain (Vavrušová 2016) examined transfers between two political regimes whose ideology was very different but which were comparable in their censorial practices. Partly based on censors' reports, these studies explored the impact of ideology and of censorship on the reception of translated literature. In turn, a study about Polish translations in Portugal (Pięta 2012) allowed a deeper understanding of indirect translation, which constituted an important means of passage of Polish literature to the readership of this authoritarian country.

The second specific case of the East-to-West translations concerns literary transfers between non-democratic regimes (where the works were produced) and democratic regimes (where they were translated); in spite of the contrast with the previous ones, they also underwent various forms of politicisation. Working on the translation of several Eastern European literatures (Czech, Slovak, Polish, Hungarian, Rumanian, and to some extent, Soviet) in one particular Western country (France), Popa (2002, 2006, 2010) analysed the plural mechanisms of such transfers, offering an approach in terms of 'translation channels'. This approach makes it possible to deepen the analysis of the differentiation of translation flows on the basis of supplementary criteria and to go beyond binary and rigid oppositions between authorised/non-authorised transfers and authors' submission/dissidence. The parameters it took into account were the time of publication (before/after 1947), as well as the material support of the source-text (not only published books, but also the unconventional and unauthorised editions called samizdat, editions published in exile, previous foreign translations, manuscripts submitted for publication directly in French or in other Western languages), the legal vs. illicit status of the text at the moment when it was 
Popa I., "Translation and Communism in Eastern Europe", in Fruela Fernandez and Jonathan Evans (eds.), Routledge Handbook of Translation and Politics, London, Routledge, 2018, pp. 424-441

being published and translated, and the geographical location and progression of the sourcetext (publication within the national boundaries, transit via publishers in exile or via Western publishers other than the French ones). The combination of these parameters allows six specific translation channels to be patterned ('exportation', 'official', 'patrimonial', 'semiofficial', 'parallel' and 'direct'). Each channel displays different kinds of trajectories for a text, leading from a manuscript to its translation. This diversification applies even within specific categories of source-texts and to various components of the body of work of the same author. To give but one example, literary works that were all published before the establishment of communism could henceforth be translated in different ways: through the 'patrimonial' channel, if such a work was still an authorised reference and if its author capitalised on the fame already achieved in the previous state of the literary field and was recognized by the literary value system of the new regimes as well; through the 'exportation' channel, if its author was considered useful to embody the new socialist literary canon that official policies sought to showcase to a foreign readership; but these works could also be translated through the 'parallel' channel after being published in samizdat or in exile in cases where their author was banned under communism, although he/she had been previously a canonised writer. Hence this approach reveals a gradation according to the institutionalisation and politicisation of the literary transfer, as well as the interactions, porosities and even overlappings between an authorised and a regulated space of publishing and translating, on the one hand, and a clandestine and an underground space of production and circulation of texts, on the other hand. Identifying several modalities of international circulation of texts thus enriches this opposition, giving us a differentiated and a dynamic view of the mechanisms of literary transfer and an insight into the articulation between state players and the transnational networks that underlay this transfer.

This analytical perspective can be replicated at the level of the Eastern European countries' cultural spheres, as the parameters that helped construct the notion of 'translation channels' are also operational in the case of the transfers towards these countries, allowing us to gain a more precise understanding of their own modalities. In spite of repressive and levelling political constraints, these modalities preserved some plurality; therefore, an approach in terms of 'translation channels' can be reapplied in a more or less loose way for examining them. To use the same example, translation of the Western canonised authors' works had to cope with the requirements of censorship. Therefore, at least for some periods of time, official publishing houses favoured the translation of classic writers' works belonging to 'progressive' and 'realistic' literary traditions of the $19^{\text {th }}$ century and early $20^{\text {th }}$ centuries (Špirk 2008, among others). This choice also contributed to placing contemporary literary developments, and in particular Socialist Realism, into historical perspective and thus to legitimate them. At the same time, however, this 'patrimonial' preference allowed the promotion of Western literatures in translation to be preserved, constituting a sort of bulwark against purely ideological choices, even more so during periods when restrictions on contemporary literature were too severe.

\section{AUTHORISED AND REGULATED SPHERE VS. UNDERGROUND AND EXTERNALISED PUBLISHING AND TRANSLATION PRACTICES}

By adopting a differentiated approach to literary transfers, scholars can examine institutions and individual players involved in publishing translations not only within an authorised and 
Popa I., "Translation and Communism in Eastern Europe", in Fruela Fernandez and Jonathan Evans (eds.), Routledge Handbook of Translation and Politics, London, Routledge, 2018, pp. 424-441

regulated sphere of institutions and practices, but also within an underground and clandestine one, while identifying some variations within each of them.

In view of capturing these variations, the understanding of official translation policies must not only be related to more general cultural and political orientations but also be refined by embodying these policies into a plurality of institutions; they were not limited to central and repressive ones, and could have some room for manoeuvre depending on the political and local contexts. These institutions included those responsible for the exportation of national literature abroad, translating agencies, specialised publishing houses, collections and journals established in most Eastern European countries in order to support translation of foreign literatures. For example, in Romania, the State Publishing House for Literature and Arts was founded in 1953 and partly transformed into the Publishing House for World Literature in 1960, which then became the Univers publishing house in 1970; a publishing house devoted to the translation of Russian literature, Russian Book, was also created. Specialised collections, such as the prestigious Classics of the World literature in the Romanian language, as well as the series The Gold Fund of Literature in Translation into the Slovak language (created in the late 1960s) offer an additional level of analysis. This was also the case for journals dedicated to world literature in translation - for instance, the Polish Literatura na Świecie (Stróżyński 2010) established in 1971, the Romanian Secolul XX, in 1961, and the Slovak Revue svetovej literatúry, in 1965. Taking into account diversified support materials within the authorised sphere - in this case, not only books but also articles - would allow verifying whether journals could more easily make source texts 'acceptable' for censors and publish translations more rapidly than long length texts that were edited as books by publishing houses.

Editorial offices specialised in drama translation were created as well. They aimed at publishing translations for professional and amateur theatre groups, while being linked with different censorship bodies (Antohi 2012, for the Romanian case) and with the Theatre and Literary Association (Bednárová 2015: 89, for the Slovak case). This official institutional background also includes the creation of translation prizes. They not only brought fame to individual translators, but also increased the visibility and recognition of the translator's profession. For example, the Ján Hollý Prize was established by the Slovak Literary Fund in 1967. After the communist regimes came to power, the creation of distinct sections devoted specifically to translation within the Writers' Unions (Friedberg 1997: 191-201; ThomsonWohlgemuth 2004: 504-505, 2009: 107-114; Laurent 2014: 223-243) also played an important role in institutionalising these activities and recognising translators' professional status, and not just in controlling their practices. Translation was thus recognised as a part of national literature and as a means of literary creation, and not just as a technique, whereas translators were considered creators and attributed the same rights and advantages as the writers themselves. Besides, membership of this section could also include writers whose works had been forbidden but who could nevertheless publish translations they had made under their own names, and therefore to belong to the Writers' Union. This corporate association monopolised the access to the status of writer and, in each Eastern European country, also managed a sizeable infrastructure (journals, publishing houses, state budgetary support, leisure and health facilities). It also provided institutional backing for debates, conferences and literary exchanges with other socialist countries. However, the role of the Writers' Union depended greatly on the political circumstances: it could act as a 'transmission belt' for the political power, but it also protected its members, and even took the forefront of political protests for liberalisation. This was the case, for instance, for the 
Popa I., "Translation and Communism in Eastern Europe", in Fruela Fernandez and Jonathan Evans (eds.), Routledge Handbook of Translation and Politics, London, Routledge, 2018, pp. 424-441

Hungarian Writers' Union in 1956 and of the Czech Writers' Union in 1968, at the time of the Prague Spring. On the basis of the reports of the Translation Section of the Polish Writers' Union, Laurent (2014: 239-241) has also shown attempts by translators themselves to regain some autonomy in their professional choices during the Thaw, in the mid-1950s.

Writers' Unions also played a role in translators' training, as well as in the gradual organisation and development of their profession. For instance, a Circle of Translation was created for this purpose within the Slovak Translation Section of the Union of the Czechoslovak Writers in 1949 (Bendarova 2013: 262-263). While the Translation Sections of the Writers' Union had been considered as the first translators' associations in the Eastern European countries, distinct professional associations would be created later on. In Romania, for instance, a Professional Union of Interpreters and Translators was established in 1990 (that is, after the collapse of communism), as was the Slovak Literary Translators Society, whereas an Association of Polish Translators and Interpreters had already been founded, and became a member of the International Federation of Translators, in 1981.

Moreover, the understanding of the general process of professionalisation of translating activities, as well as of educational background of new generations of translators, implies taking into account the gradual establishment of specialised university curricula, degrees and centres delivering them. For instance, in Slovakia (Vajdová 2013; Jettmarová 1993), a seminar on literary translation was established in 1949/1950 at Comenius University. However, teaching of translation at the academic level started mainly from the 1970s onwards: an Institute of Translation Studies and Interpreting was created at the University of November $17^{\text {th }}$ in Bratislava in 1970, whereas a postgraduate course was established at the University of Nitra in 1973. Likewise, in Hungary, a Training Centre for Translators and Interpreters was established at the University of Budapest in the same year. This process favoured translators' training and gradually reduced the heterogeneity of their education and professional trajectories, still persistent during the $20^{\text {th }}$ century, while standardising the transmission of linguistic skills. Furthermore, the academic sector and editorial sphere cannot be disconnected since the former also occasionally provided the latter with referees, consultants and experts for evaluating texts and even for designing translation programmes. Finally, academia also provided an institutional and intellectual framework for developing theoretical approaches complementing the reflection on methods and procedures, as well as practice itself.

These theoretical approaches gradually took new avenues, different from those established during earlier debates about a Marxist-Leninist translation theory. Indeed, at the beginnings of communist regimes, a 'realistic translation', the correlative of Socialist Realism (Leighton 1991: 63-81), was elaborated in the USSR and debated in other socialist countries as well, such as in the GDR (Thomson-Wohlgemuth 2004: 501-503). Following this view, the translator could be, and even was to be, a kind of propagandist, like the socialist realist writer. Armed not only with linguistic skills but also with knowledge about politics and social developments and an appropriate ideological attitude, he had to spot positive elements within the source text and to transmit them to the reader, even if this vision was partial. A debate over literal vs. free translation also occurred first among Soviet (Friedberg 1997: 69113; Leighton 1991: 58-94), then East European translators. The first approach was officially denounced in the 1930s as a manifestation of formalism, then of cosmopolitanism. Some scholars have interpreted this preference for free translation as having facilitated censorship. Other translation approaches were analysed in connection with the political 
Popa I., "Translation and Communism in Eastern Europe", in Fruela Fernandez and Jonathan Evans (eds.), Routledge Handbook of Translation and Politics, London, Routledge, 2018, pp. 424-441

issues they raised previously in the USSR, such as the use by adaptors of interlinear trots produced by native speakers (Friedberg 1997: 172-177; Witt 2011: 160-163).

However, along with the gradual institutionalisation of the pedagogical activity, new theoretical reflections developed through seminars, conferences, research institutes of the Academies of Sciences. In certain Eastern European countries, for example the former Czechoslovakia, they also coalesced through the establishment of translation 'schools', such as the Nitra school formed in the early the 1960s (Vajdová 2013; Jettmarová 2008). Whereas its theoretical foundations came partially from the Prague Linguistic Circle and the first generation of Czech structuralism, as well as from Russian formalism, the Nitra school developed a communication-based and semiotic conception of translation, emancipating it from philology and comparative literature. Its main protagonists were Anton Popovič and František Miko, whose pioneering efforts gained international recognition and also contributed to building worldwide contacts, along with those of the Czech translation theorist and literary historian Jiři Levý (Beylard-Ozeroff, Králová and Moser-Mercier 1998; Jettmarová 2008), and of Dionýz Ďurišin, a Slovak literary theorist and comparativist. Among other initiatives, Anton Popovič founded in 1975 the Translation Summer School that functioned like a post-graduate course and contributed to the training of new generations of translators. Theoretical work on translation was also deployed at the Institute of World Literature and Languages in Bratislava. It existed as an autonomous body within the Slovak Academy of Science between 1964 and 1973, and then was merged into a general Institute of Literary Studies during the restrictive context that halted the reforms of the Prague Spring period in Czechoslovakia.

Such contexts of increased censorship and containment stimulated unauthorised publishing and translation practices and the establishment of an underground system of printing and clandestine distribution. Journals and publishing houses were thus created especially from the 1970s on, some by banned writers (such as Ludvík Vaculík and Václav Havel, who founded Edice Petlice and Edice Expedice, respectively, in Czechoslovakia) and translators (such as Jan Vladislav, the founder of Kvart, in the same country), but also by individuals who did not belong to literary milieus (such as the founder of the Polish publishing house NOWA). This underground system connected with literary institutions that had been developed in exile: journals (such as the Polish Kultura, the Czech Sverdectví, the Hungarian Irodalmi Újság, the Russian Kontinent, established in Paris) as well as publishing houses (like the Institut littéraire and YMCA Press in Paris, Index in Cologne, Sixty-Eight Publishers in Toronto, Ardis in Michigan). Samizdat could lead to translation either directly or passing through these externalised institutions. The articulation of the internal and external unauthorised publication channels (Popa 2010, Kind-Kovacs and Labov 2013) relied on the gradual building of transnational networks of intermediaries and smugglers, and accomplished through different material supports that banned texts could successively take. These connections gradually increased the diffusion of unauthorized translated texts, in both quantitative and geographic terms. Moreover, once again, there were no merely one-sided literary transfers but crossed ones: translation of samizdat into Western languages on the one hand, of Western literature as well as of other prohibited Eastern European texts into samizdat, on the other hand. For example, NOWA published translations of works by authors who were not 'ideologically' acceptable, such as Aleksandr Solzhenitsyn, Zdeněk Mlynář, and George Orwell. Moreover, in the USSR and Czechoslovakia, there were no official Soviet or Czech editions, respectively, of works by exiled writers Vladimir Nabokov and Milan Kundera, 
Popa I., "Translation and Communism in Eastern Europe", in Fruela Fernandez and Jonathan Evans (eds.), Routledge Handbook of Translation and Politics, London, Routledge, 2018, pp. 424-441

which had been originally been published in English and in French; however, unauthorised copies, published in exile or in samizdat, were in circulation in these countries.

Far from a single and univocal picture of translating practices and players generated by the exercise of power under undemocratic regimes, the Eastern European area offers a precious terrain for observing a plurality of interactions between literary translation and politics. Examining these connections enriches our historical and sociological understanding of the functioning of communist regimes, as well as of translation as a social practice.

\section{Related topics}

Translation and cultural diplomacy, Translation and Censorship, Translation and the Cold War, Translation and Marxism, Translation and multilingual states

\section{Further readings}

Bart, István (2000) Világirodalom és könyvkiadás a Kádár-korszakban, Budapest, Scholastica: an insight on the translation of world literature in Hungary and the book publishing system during the Kádár era under communism.

Hrala, Milan et al. (2002) Kapitoly z dějin českého překladu, Praha, Karolinum: an overview on different moments of the history of the Czech translation.

Lungu-Badea, Georgiana (ed.) (2008) Un capitol de traductologie românească. Studii de istorie a traducerii, Timisoara, Editura Universităţii de Vest: an insight in the history of translation in Rumanian language during the 18th and 19th centuries.

Skibińska Elżbieta, Kuchnia tłumacza: studia o polsko-francuskich relacjach przekładowych, Kraków, Universitas, 2008: a study providing a theoretical background along with historical overviews of French translations of post-war Polish prose and the post-war French novel in Polish translation, supported by quantitative data.

\section{References}

Antochi, Roxana-Mihaela (2012) 'Communist Ideology and Drama Translation in Romania', in E. Parra-Membrives, M. García Peinado and A. Classen (eds) Aspects of Literary Translation. Building Linguistic and Cultural Bridge in Past and Present, Tübingen: Narr Francke Attempto, 253-264.

Autio-Sarasmo, S. and K. Miklossy, eds (2011) Reassessing Cold War Europe. London: Routledge

Baer, B. J. (2006) 'Literary Translation and the Construction of a Soviet Intelligentsia', The Massachusetts Review, 47-3: 537-560

Baer, B. J. (ed.) (2011) Contexts, Subtexts and Pretexts. Literary Translation in Eastern Europe and Russia, Amsterdam/Philadelphia: John Benjamins.

Baudin A. and L. Heller (1998) Le réalisme socialiste soviétique de la période jdanovienne, 1947-1953, Vol. 2, Bern: Peter Lang. 
Popa I., "Translation and Communism in Eastern Europe", in Fruela Fernandez and Jonathan Evans (eds.), Routledge Handbook of Translation and Politics, London, Routledge, 2018, pp. 424-441

Bednárová, K. (2013) Dejiny umeleckého prekladu na Slovesnku I. Od sakralneko k profánnemu, Bratislava: VEDA, 239-280.

Bednárová, K. (2015) 'Contexts of Slovak Literary Translation of 20th Century', in O. Kovačičová and M. Kusá (eds), Sloveník Slovenských Prekladatel'ov Umeleckej Literatúry. 20. storočie. Bratislava: VEDA, 74-92.

Berger, E. (2013) Rezeption österreichischer Literatur in Rumänien 1945-1989, Berlin: Frank \& Timme.

Beylard-Ozeroff A., J. Králová and B. Moser-Mercier (1998) Translation Strategies and Creativity. In Honor of Jiři Levý and Anton Popovič, Amsterdam: John Benjamins.

Bourdieu, P. (1992). Les règles de l'art. Genèse et structure du champ littéraire, Paris, Seuil.

Chernetsky, V. (2011) 'Nation and translation. Literary translation and the shaping of modern Ukrainian culture' in Contexts, Subtexts and Pretexts. Literary Translation in Eastern Europe and Russia, Baer, B.J. (ed.), Amsterdam/Philadelphia: John Benjamins, 33-53.

Clark K. (2011) Moscow, the Fourth Rome. Stalinism, Cosmopolitanism, and the Evolution of Soviet Culture, 1931-1941 Cambridge: Harvard UP.

David-Fox M. (2011a) 'The Implications of Transnationalism', Kritika 12(4): 885-904.

David-Fox M. (2011b) Showcasing the Great Experiment: Cultural Diplomacy and Western Visitors to Soviet Russia, 1921-1941, New York: Oxford UP.

Deletant D. 1996. 'The Debate between Tradition and Modernity in the Shaping of a Romanian identity', in R. Pynsent, The Literature of Nationalism. Essays on East European Identity, Basingstoke/London: Macmillan Press, 14-26.

Dimitriu, I. (2006) 'Symbolic Power' and 'Worldmaking' in Politically Over-Determined Times: Translation and Social Practice under Dictatorship' in M. Wolf (ed.), Übersetzen Translating-Traduire: towards a "Social Turn"?, Wien: Lit Verlag, 55-64.

Dimitriu, R. (2000) 'Translation policies in pre-communist and communist Romania: the case of Aldous Huxley', Across Languages and Cultures 1(2): 179-192.

Dobry, M. (2003) 'La thèse immunitaire face aux fascismes. Pour une critique de la logique classificatoire', in M. Dobry (ed.), Le mythe de l'allergie française au fascisme, Paris: Albin Michel, 17-67.

Dragomir, L. (2006) 'Les échanges culturels de I'Union des écrivains de Roumanie dans les années 1960', Etudes de lettres 1-2: 151-168.

Fitzpatrick, S. (1986) 'New Perspectives on Stalinism', The Russian Review 45(4): 357-373

Friedberg, M. (1997) Literary Translation in Russia: a Cultural History, University Park, Pennsylvania: The Pennsylvania State UP

Gorhal, M. (2003) Speaking in the Soviet Tongues: Language Culture and the Politics of Voice in the Revolutionary Russia, DeKalb, Ill.: Northrn Illinois UP.

Grenoble, L. (2003) Language Policy in the Soviet Union, Dordrecht/Boston/London: Kluwer Academic Publishers.

Heilbron, J. (1999) 'Towards a Sociology of Translation. Book Translations as a Cultural World System', European Journal of Social Theory 2(4): 429-444.

Inggs, J. (2011) 'Censorship and translated children's literature in the Soviet Union. The Example of the Wizards $\mathrm{Oz}$ and Goodwin', Target. International Journal of Translation Studies 23(1): 77-89.

Ionescu, A. (2010) 'Un-sexing Ulysses: the Romanian translation 'under' communism', Scientia Traductionis 8: 237-252.

Jettmarová, Z. (1993) 'Translator Training and Translation Studies in the Czech and Slovak Republics', Parallèles 15: 13-15 
Popa I., "Translation and Communism in Eastern Europe", in Fruela Fernandez and Jonathan Evans (eds.), Routledge Handbook of Translation and Politics, London, Routledge, 2018, pp. 424-441

Jettmarová, Z. (2008) 'Czech and Slovak Translation Theories. The Lesser-known Tradition', in J. Králová, Z. Jettmarová (eds), Tradition versus Modernity: from the Classic Period of the Prague School to Translation Studies at the Beginning of the $21^{\text {st }}$ Century, Prague: Charles University, 15-46.

Joachim F. and Z. Brezinski (1956) Totalitarian Dictatorship and Autocracy, Cambridge, Mass.: Harvard UP.

Johnston, G. (2010) 'Revisiting the cultural Cold War', Social History 35(3): 290-307

Kind-Kovacs F. and J. Labov (eds) (2013) Samizdat, Tamizdat, and Beyond: Transnational Media During and After Socialism, New York: Berghahn Books

Konràd G. and I. Szelényi (1979) The Road of Intellectuals to Class Power, New York: Harcourt.

Laurent, M. (2014) 'La traduction en Pologne à l'époque stalinienne (1949-1956)', in M. Laurent (ed.), Traduction et rupture, Paris: Le Rocher de Calliope/Numilog, 223-243.

Leighton, L. (1991) Two Worlds, One Art: Literary Translation in Russia and America, Illinois: Northen Illinois UP.

Lewis M. and K. Wigen (1997) The Myth of Continents: A Critique of Meta-Geography, Berkely: University of California Press.

Looby, R. (2008) 'Looking for the Censor in the Works of Sean O'Casey (and Others) in Polish Translation', Translation and Literature, 17: 47-54.

Loseff, L. (1984) On the Beneficence of Censorship: Aesopian Language in Modern Russian Literature. Munich: Sagner.

Malia, M. (1994) Soviet Tragedy. A History of Socialism in Russia 1917-1991, Free Press.

Monticelli D. (2011) 'Totalitarian Translation' as a Means of Forced Cultural Change: the Case of Postwar Soviet Estonia', in A. Chalvin, A. Lange, D. Monticelli (eds), Between Cultures and Texts: Itineraries in Translation History, Frankfurt am Main/ Berlin/Bern/Bruxelles/New York/Oxford/Wien: Peter Lang, 187-200.

Péteri, G. (2004) 'Nylon Curtain: Transnational and Transsystemic Tendencies in the Cultural Life of State-Socialist Russia and East-Central Europe', Slavonica 10(2): 113-23.

Pięta, H. (2012) 'Patterns in (in)directness An exploratory case study in the external history of Portuguese translations of Polish literature (1855-2010)', Target 24(2): 310-337.

Popa, I. (2002) 'Un transfert littéraire politisé. Circuits de traduction des littératures d'Europe de l'Est en France 1947-1989', Actes de la recherche en sciences sociales, 144: 55-69.

Popa, I. (2006) 'Translations Channels. A Primer on Politicized Literary Transfer', Target. International Review of Translation Studies 18(2): 205-228.

Popa, I. (2010) Traduire sous contraintes. Littérature et Communisme, Paris: CNRS Editions.

Popa, I. (2013) 'Communism and Translation Studies', in L. van Doorslaer and Y. Gambier (eds), Handbook of Translation Studies, vol. 4, Amsterdam/Philadelphia: John Benjamins, 25-30.

Rădulescu, A. (2010) 'Entre censure et autocensure littéraire en Roumanie: I'odyssée d'un journal intime à l'époque communiste', TTR 23(2): 23-52.

Rudd, C. (2009), Fighting Words: Imperial Censorship and the Russian Press, 1804-1906. Toronto: University of Toronto Press.

Safiullina N. and R. Platonov (2012) 'Literary Translation and Soviet Cultural Politics in the 1930s: the Role of the Journal Internacional'naja literatura', Russian Literature 72(2): 239-269.

Sherry, S. (2010) 'Censorship in Translation in the Soviet Union: the Manipulative Rewriting of Howard Fast's The Passion of Sacco and Vanzetti', Slavonica 16(1): 1-14. 
Popa I., "Translation and Communism in Eastern Europe", in Fruela Fernandez and Jonathan Evans (eds.), Routledge Handbook of Translation and Politics, London, Routledge, 2018, pp. 424-441

Shevelov George Y. 1989. The Ukrainian Language in the First Half of the Twentieth Century (1900-1941): Its State and Status. Cambridge, Harvard UP.

Skibińska, E. (2006) 'La traduction au service de l'idéologie. 'Liste de lectures françaises' en polonais dans les années 1946-1960', in M. Wolf (ed.), Übersetzen - Translating Traduire: towards a "Social Turn"?, Wien: Lit Verlag, 131-141.

Špirk, J. (2008) 'Translation and Censorship in Communist Czechoslovakia', in T. Seruya and M. Lin Moniz, Translation and Censorship in Different Times and Landscapes, Newcastle: Cambridge Scholars Publishing, 215-228.

Špirk, J. (2014) Censorship, Indirect Translations and Non-translation. The (Fateful) Adventures of Czech Literature in 20th-century Portugal, Newcastle: Cambridge Scholars Publishing.

Stróżyński T., (2010) 'La littérature française dans la revue polonaise Literatura na Świecie (1971-2008)', in M. Laurent (ed.), La littérature française en traduction, Paris: Le Rocher de Calliope/Numilog, 97-112.

Swaan de, A. (1993) 'The Emergent World Language System', International Political Science Review 3: 219-226.

Tax Choldin, M. (1985) A Fence around the Empire: Russian Censorship of Western Ideas under the Tsars, Durham: Duke UP.

Tax-Choldin, M. (1986) 'The New Censorship: Censorship by Translation in the Soviet Union', The Journal of Library History 21(2): 334-349.

Thomson-Wohlgemuth, G. (2004) 'A Socialist Approach to Translation: a Way Forward?' Meta, 49(3): 598-510.

Thomson-Wohlgemuth, G. (2007) 'On the Other Side of the Wall. Book Production, Censorship and Translation in Eastern Germany', in F. Billiani (ed.), Modes of Censorship and Translation: National Contexts and Diverse Media, Manchester: St. Jerome, 93-116.

Thomson-Wohlgemuth, G. (2009) Translation under State Control. Books for Young People in the $D D R$, London/NY, Routledge.

Todorova, M. 1997. Imagining the Balkans, Oxford, Oxford UP.

Tomaszkiewicz, T. (2002) 'La censure des textes censurés', TTR 15(2): 171-189.

Tymoczko, M. (ed.) (2010) Translation, Resistance, Activism, Amherst/Boston: University of Massachussetts Press.

Vajdová L. (ed.) (2013) Present State of Translation Studies in Slovakia, Bratislava: Slovak Academic Press.

Verdery K. (1991) National Ideology Under Socialism: Identity and Cultural Politics in Ceauşescu's Romania, Berkeley: University of California Press.

Villaume P. and O. A. Westad (eds) (2010) Perforating the Iron Curtain. European Détente, Transatlantic Relations and the Cold War, 1965-85, Copenhagen: Museum Tusculanum Press.

Wachtel, A. (2006) Remaining Relevant After Communism: The Role of the Writer in Eastern Europe, Chicago: Chicago UP.

Westad, O. A. (ed.) (2000) Reviewing the Cold War: Approaches, Interpretations, Theory. London: Frank Cass Publishers.

Witt, S. (2011) 'Totalitarianism and translation in USSR', in B. J. Baer (ed.), Contexts, Subtexts and Pretexts. Literary Translation in Eastern Europe and Russia, Amsterdam/Philadelphia: John Benjamins, 149-170.

Wolff, L. (1994) Inventing Eastern Europe. The Map of Civilization on the Mind of the Enlightenment, Stanford: Stanford UP. 